\title{
Perancangan Sistem Aktuator Laju Aliran Masuk dan Simulasi Proses Netralisasi pH pada Plant Simulator Instalasi Pengolahan Air Limbah Industri Tekstil (IPLIT)
}

\author{
1Elfi Yulia *), 2Estiyanti Ekawati \& 2 Eko Mursito Budi \\ ${ }_{1}^{1}$ Pusat Teknologi Instrumentasi dan Otomasi, Institut Teknologi Bandung \\ ${ }^{2}$ Kelompok Keahlian Instrumentasi dan Kontrol, Institut Teknologi Bandung \\ elfi@instrument.itb.ac.id*)
}

\begin{abstract}
Abstrak
Peningkatan produk tekstil diiringi dengan peningkatan jumlah limbah tekstil namun pengolahan limbah belum memenuhi standar dan menyebabkan pencemaran lingkungan seperti di DAS Citarum. Keluaran limbah industri tekstil memiliki tingkat keasaman $\mathrm{pH}$ 8-10 sedangkan standar $\mathrm{pH}$ limbah berada di rentang 6-9. Untuk mendukung upaya penurunan $\mathrm{pH}$ limbah dilakukan penelitian yang difokuskan terhadap proses netralisasi $\mathrm{pH}$ pada Instalasi Pengolahan Air Limbah Industri Tekstil (IPLIT).
\end{abstract}

Proses netralisasi $\mathrm{pH}$ pada simulator IPLIT merupakan proses reaksi kimia untuk menurunkan $\mathrm{pH}$ limbah dengan melibatkan limbah mengandung basa kuat $\mathrm{NaOH}$ dan penetral asam lemah $\mathrm{CH}_{3} \mathrm{COOH}$. Pada penelitian ini, dirancang sistem aktuator laju aliran masuk air limbah dan penetral menggunakan pompa DC jenis submersible water pump yang dihubungkan dengan modul L298 dan pengontrol mikrokontroller. Modul L298 berperan dalam mengontrol kecepatan dan arah putaran motor DC berdasarkan Pulse Width Modulation yang ditentukan pengontrol. Selanjutnya sensor flowmeter akan membaca jumlah pulsa sebanding dengan laju aliran masuk yang terhubung ke mikrokontroller. Hasil pengukuran antara pompa, flowmeter dan $\mathrm{pH}$ meter menunjukkan bahwa laju aliran masuk limbah pada proses netralisasi $\mathrm{pH}$ adalah antara $0.8 \mathrm{~L} / \mathrm{m}$ hingga $1 \mathrm{~L} / \mathrm{m}$ dan laju aliran masuk penetral antara $0.6 \mathrm{~L} / \mathrm{m}$ hingga $1 \mathrm{~L} / \mathrm{m}$. Berdasarkan parameter laju aliran masuk tersebut diperoleh hasil simulasi proses netralisasi $\mathrm{pH}$ dari simulator iplit IPLIT berupa konsentrasi limbah yang dapat diproses adalah pH 9-10 dan penetral yang dapat digunakan adalah $\mathrm{pH} 4$ dan 5 .

Kata Kunci: limbah tekstil, netralisasi $\mathrm{pH}$, simulasi netralisasi $\mathrm{pH}$, IPLIT, aktuator pompa

\section{Pendahuluan}

Sektor industri tekstil merupakan sektor penting untuk meningkatkan perekonomian Indonesia dengan ekspor mencapai US\$7,12 miliar dan menyerap tenaga kerja hingga 2,73 juta jiwa di tahun 2017 [1]. Peningkatan produk tekstil diiringi dengan peningkatan jumlah limbah tekstil namun pengolahan limbah belum dilakukan sesuai standar menyebabkan terjadinya pencemaran lingkungan seperti di DAS Citarum[2].

Menurut CNN Indonesia, pencemaran di sekitar DAS Citarum disebabkan oleh kurangnya penggunaan Instalasi Pengolahan Air Limbah (IPAL). Diketahui, 64 perusahaan dari 444 perusahaan industri tekstil yang berada di DAS Citarum belum memiliki IPAL. Sedangkan sisanya, 380 perusahaan yang telah memiliki IPAL pun belum sepenuhnya mengolah limbah sesuai dengan mutu yang disyaratkan disebabkan oleh biaya pengolahan limbah yang mahal dan waktu yang lama [3].

Limbah tekstil termasuk golongan limbah B3 (Bahan Berbahaya Beracun) berdasarkan PP No. 101 tahun 2014. Pembuangan limbah harus sesuai dengan baku mutu limbah yang ditetapkan pada KEP-51/MENLH/10/1995 salah satunya harus berada pada $\mathrm{pH}$ direntang 6-9 [4]. Sedangkan limbah industri tekstil memiliki karakteristik $\mathrm{pH}$ dalam kondisi basa tinggi berasal dari proses scouring dan mercerizing. Gabungan dari proses proses pembuatan tekstil menghasilkan limbah dengan pH antara 8-10 [5].

Untuk mendukung upaya pembuangan limbah industri tekstil sesuai dengan baku mutu limbah, penelitian ini difokuskan untuk merancang sistem proses netralisasi $\mathrm{pH}$ pada simulator Instalasi Pengolahan Air Limbah Industri Tekstil (IPLIT). Perancangan difokuskan pada sistem laju aliran masuk air limbah dan penetral dan simulasi proses netralisasi $\mathrm{pH}$ menggunakan perangkat lunak.

\section{Proses Netralisasi $\mathrm{pH}$}

Proses netralisasi pH merupakan proses reaksi kimia yang terjadi antara larutan asam dan basa untuk mencapai $\mathrm{pH}$ yang diinginkan. Proses netralisasi $\mathrm{pH}$ pada IPLIT bertujuan menetralkan limbah industri tekstil yang telah homogen dari tangki equalisasi ( $\mathrm{pH}$ 8-10) menjadi limbah yang sesuai dengan standar ( $\mathrm{pH}$ 6-9). Proses ini 
melibatkan limbah kondisi basa kuat dengan penetral asam lemah untuk mencapai nilai $\mathrm{pH}$ sesuai diinginkan.

Berdasarkan literatur, model dinamik (1) dan (2) proses netralisasi $\mathrm{pH}$ untuk pengolahan air limbah pertama kali diperkenalkan oleh McAvoy, dkk tahun 1972 menggunakan tangki Controlled Stirred Tank Reactor (CSTR) antara basa kuat dan asam lemah. Model dinamik ini telah digunakan untuk beberapa penelitian terdahulu seperti pada penelitian perancangan purwarupa instalasi pengolahan air limbah industri tekstil antara basa kuat dan asam lemah [6]. Selanjutanya, untuk merancang Internal Mode Control pada proses netralisasi limbah melibatkan basa kuat dan asam kuat [7]. Kemudian, model ini digunakan untuk perancangan kontrol Neural Network PID Control antara basa kuat dan asam kua [8].

Model dinamik yang digunakan merupakan 2 buah turunan differential berupa proses disosiasi asam $\left(x_{1}\right)$ dan disosiasi basa $\left(x_{2}\right)$ dipengaruhi oleh laju aliran masuk asam $F_{a}$, laju aliran masuk limbah $F_{b}$, konsentrasi asam $C_{a}$ dan konsentrasi limbah $C_{b}$. Persamaan (1) dan (2) menunjukkan persamaan dinamik pada tangki netralisasi

$$
\begin{aligned}
& \frac{d x_{1}}{d t}=\frac{F_{a} \cdot C_{a}}{V_{t}}-\frac{F_{a}+F_{b}}{V_{t}} x_{1} \\
& \frac{d x_{2}}{d t}=\frac{F_{b} \cdot C_{b}}{V_{t}}-\frac{F_{a}+F_{b}}{V_{t}} \cdot x_{2}
\end{aligned}
$$

Sedangkan volume akhir larutan pada tangki $V_{t}$ pada persamaan (3) dipengaruhi oleh volume awal larutan di tangki $V_{0}$ ditambah banyaknya aliran yang masuk tiap waktu

$$
V_{t}=V_{o}+F a . t+F b . t
$$

\section{Perancangan Sistem Laju Aliran Masuk}

Proses perancangan sistem laju aliran masuk berdasarkan pada process flow diagram pada Gambar 1 dengan proses netralisasi $\mathrm{pH}$ ditunjukkan oleh Gambar 2. Gambar 1 memperlihatkan tangki limbah memiliki $\mathrm{pH}$ besar dari 9 sedangkan tangki penetral memiliki pH kecil dari 7. Guna mencapai pH yang diinginkan, dilakukan pengaturan terhadap laju aliran masuk dari limbah dan penetral serta konsentrasi dari kedua larutan tersebut. Pada penelitian ini, air limbah yang digunakan mengandung basa kuat $\mathrm{NaOH}$ sedangkan penetral berupa asam lemah $\mathrm{CH}_{3} \mathrm{COOH}$.

Perancangan sistem laju aliran masuk proses netralisasi $\mathrm{pH}$ melibatkan beberapa sensor dan aktuator. Sensor yang digunakan adalah sensor pHmeter yang merupakan sensor digital yang digunakan untuk mengukur tingkat keasaman suatu cairan dengan rentang pengukuran $\mathrm{pH} \mathrm{0-14}$ tingkat akurasi $\pm 0.1 \mathrm{pH}, 25{ }^{\circ} \mathrm{C}$. Selanjutnya, sensor temperatur untuk mengukur temperatur larutan yang berada di tangki netralisasi $\mathrm{pH}$ dengan rentang pengukuran $-55^{\circ} \mathrm{C}$ hingga $125^{\circ} \mathrm{C}$ dengan keakuratan $\pm 0.5^{\circ} \mathrm{C}$.

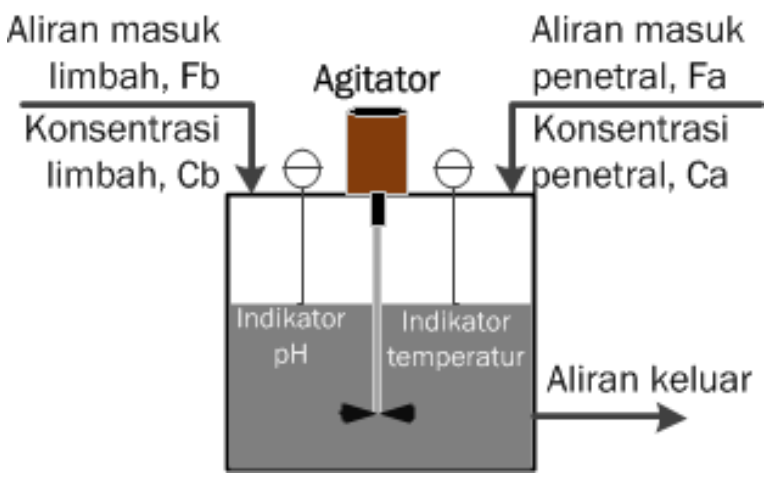

Gambar 2 Proses Netralisasi pH 
Kemudian sensor flowmeter 5 Volt menggunakan putaran turbin untuk menghitung jumlah pulsa yang terukur setiap detiknya. Sedangkan aktuator yang digunakan adalah pompa 12 DC Submersible Water Pump Pompa 12 yang tahan terhadap asam dengan debit maksimum $4 \mathrm{~L} / \mathrm{m}$ maksimal ketinggian 3 meter.

Rancangan modul dapat dilihat pada Gambar 3 dimana sensor dan aktuator terhubung ke mikrokontroller sebagai pengontrol. Pompa limbah dan pompa penetral akan dihubungkan dengan modul L298. Modul L298 berperan dalam mengontrol kecepatan dan arah putaran motor DC berdasarkan Pulse Width Modulation yang ditentukan pengontrol. Modul L298 merupakan driver motor menggunakan IC L298 (dual full bridge driver) yang banyak digunakan untuk mengontrol kecepatan dan arah putaran motor DC. Modul L298 terdiri atas transistor-transistor logik (TTL) yang mudah digunakan menggunakam gerbang logika NAND dan dapat mengendalikan 2 buah motor DC. Tegangan minimum untuk masukan power adalah 5V-35V sedangkan tegangan operasi adalah $5 \mathrm{~V}$ dengan arus masukan antara 0-36mA.

Pompa limbah akan memompakan air limbah yang berasal dari tangki equalisasi dengan tinggi maksimum cairan limbah $30 \mathrm{~cm}$. Sedangkan pompa penetral akan memompakan larutan penetral yang berasal dari tangki penetral dengan ketinggian maksimum $22 \mathrm{~cm}$.

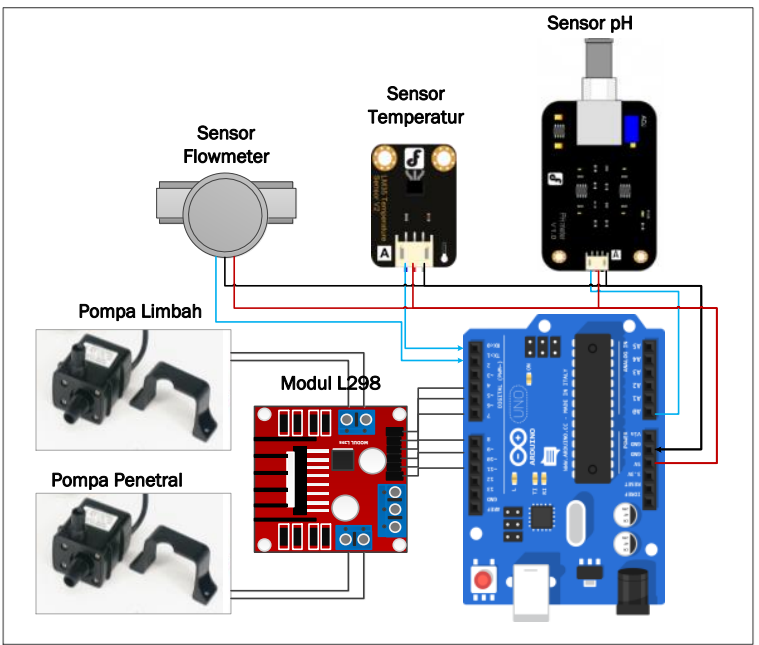

Gambar 3 Rancangan Modul

\section{Analisis}

Ketinggian dari cairan memengaruhi rentang debit yang bisa dapat dipompakan oleh pompa. Diketahui, tangki limbah dan penetral memiliki tinggi maksimum cairan adalag $35 \mathrm{~cm}$ dan $22 \mathrm{~cm}$. Untuk itu pompa dijangga agar ketinggiannya selalu stabil.

Pengujian terlebih dahulu untuk membaca laju aliran larutan melalui flowmeter selama 60 detik dengan PWM (Pulse Width Modulation) pompa dikontrol oleh pengontrol mikrokontroller. PWM yang digunakan rentang 0-255 dan ketinggian cairan pada tangki penetral tetap pada $20 \mathrm{~cm}$. Pembacaan sensor flowmeter akan dimonitoring menggunakan mikrokontroller Arduino dengan keluaran laju aliran fluida dalam liter/menit.

Berdasarkan Gambar 4 dan Gambar 5, laju aliran fluida yang masuk ke tangki cenderung stabil saat PWM besar sama dengan 25. Sedangkan ketika PWM pompa lebih kecil dari nilai tersebut, laju aliran fluida tidak stabil dan berubah setiap waktu

Pengujian berikutnya dilakukan pengamatan terhadap respon laju aliran fluida saat PWM pompa divariasikan.Gambar 6 memperlihatkan pompa juga dapat merespon perubahan PWM dengan cepat dan dibutuhkan waktu selama 2 detik bagi pompa untuk setiap perubahan dari kondisi mati ke nyala.

Berdasarkan pengujian yang telah dilakukan juga dapat diperoleh hubungan linearitas dari PWM pompa dan pembacaan laju aliran fluida yang terukur

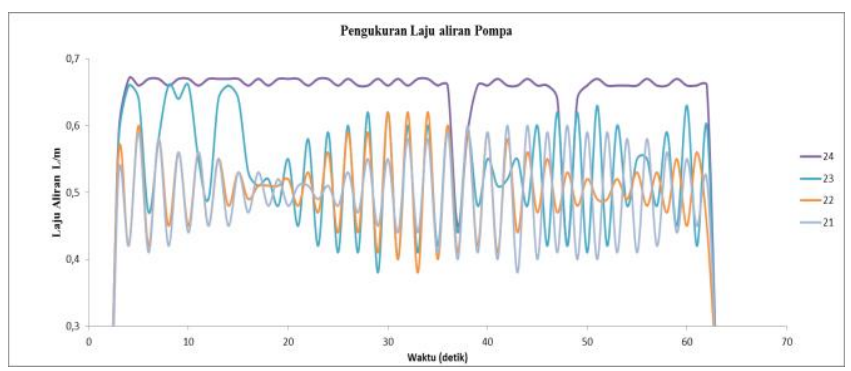

Gambar 4 Pengukuran Laju Aliran Pompa PWM 21-24

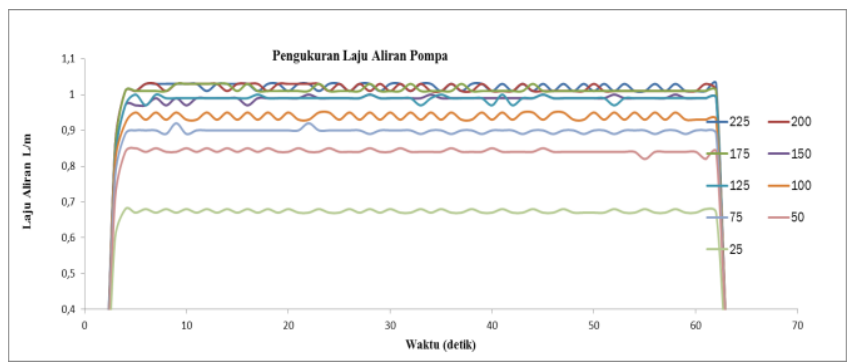

Gambar 5 Pengukuran Laju Aliran Pompa PWM 25-225 


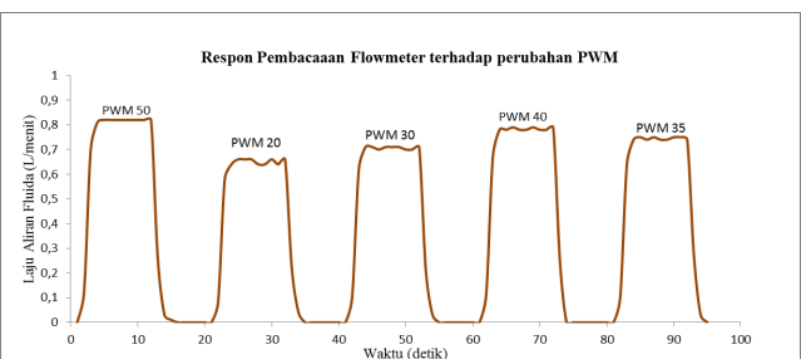

Gambar 6 Pembacaan laju aliran saat PWM bervariasi

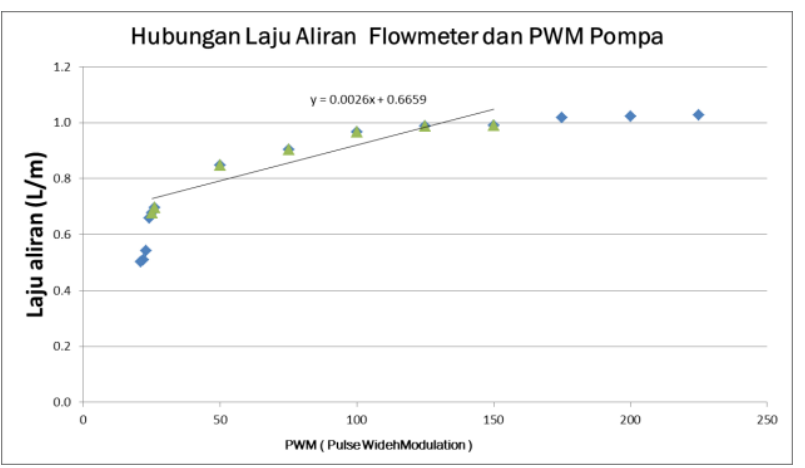

Gambar 7 Hubungan PWM pompa dan pembacaan laju aliran larutan

Gambar 7. menyatakan bahwa laju aliran fluida akan linier saat PWM pompa 25-150 dengan flow $0.69 \mathrm{~L} / \mathrm{m}$ hingga $1 \mathrm{~L} / \mathrm{m}$. Hasil pengujian ini akan digunakan sebagai masukan pada simulasi proses netralisasi $\mathrm{pH}$.

Pengujian juga dilakukan untuk mengamati respon pompa terhadap perubahan pH. Gambar 8 menunjukkan bahwa dengan modul pompa yang dirancang saat ini mampu membaca perubahan pH dengan baik dimana pompa penetral akan otomatis menyala saat larutan di tangki netralisasi $\mathrm{pH}$ memiliki $\mathrm{pH}$ diatas 9 dan pompa penetral akan mati saat larutan memiliki pH kurang dari 9.

\section{Simulasi Proses Netralisasi pH}

Simulasi proses netralisasi $\mathrm{pH}$ dirancang pada perangkat lunak matlab dengan menggunakan persamaan dinamik dari proses netralisasi $\mathrm{pH}$. Alur simulasi ditunjukkan oleh gambar 9 diawali dengan inisialisasi parameter berupa laju aliran masuk limbah, konsentrasi limbah, laju aliran masuk penetral, konsentrasi penetral, konstanta disosiasi asam (Ka). Selanjutnya, persamaan dinamika proses netralisasi pH untuk menghitung disosiasi asam dan disosiasi basa guna menentukan $\mathrm{pH}$ larutan yang dihasilkan. Terakhir digunakan solusi persamaan differensial sehingga diperoleh respon kalang terbuka

Respon kalang terbuka ditunjukkan Gambar 11 dimana $\mathrm{pH}$ awal limbah adalahh $\mathrm{pH} 9.5$ dengan penambahan penetral yang konstan diperoleh $\mathrm{pH}$ akhir larutan mendekati $\mathrm{pH} 6.5$.

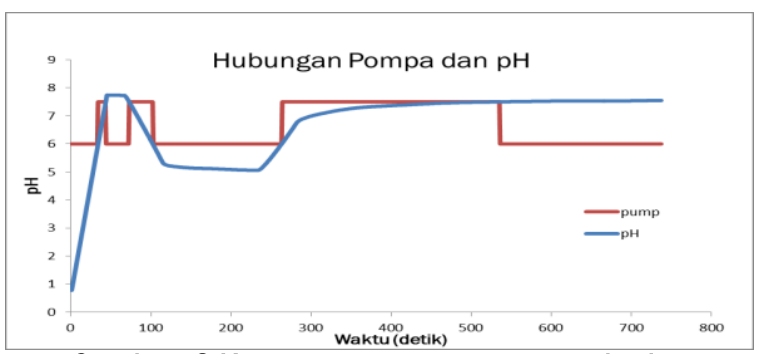

Gambar 8 Kecepatan respon pompa terhadap perubahan $\mathrm{pH}$

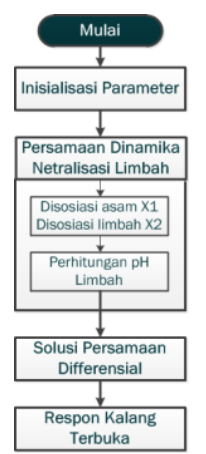

Gambar 9 Bagan Simulasi Proses Netralisasi pH

Selanjutnya simulasi dilakukan dengan mengamati pengaruh laju aliran penetral yang bervariasi terhadap laju aliran limbah tetap pada Gambar 12. Pemberian penetral dengan laju aliran $0.6 \mathrm{~L} / \mathrm{m}$, $0.8 \mathrm{~L} / \mathrm{m}$ dan $1 \mathrm{~L} / \mathrm{m}$ dapat menurunkan limbah $\mathrm{pH}$ 9.5 dengan laju aliran limbah $0.8 \mathrm{~L} / \mathrm{m}$ hingga berada di sekitar pH 6.5. Semakin besar laju aliran penetral, penurunan $\mathrm{pH}$ limbah akan lebih cepat.

Simulasi berikutnya adalah mengamati pengaruh dari konsentrasi penetral yaitu $\mathrm{pH} 4$ dan $\mathrm{pH} 5$ dengan laju aliran limbah $1 \mathrm{~L} / \mathrm{m}$ dan laju penetral 0.8 L/m. Hasil menunjukkan pada Gambar 13, penambahan penetral $\mathrm{pH} 4$ pada limbah lebih cepat menurunkan $\mathrm{pH}$ limbah dibandingkan dengan penetral 5, akan tetapi hasilnya tidak terlalu signifikan. Berdasarkan hasil ini, masih bisa dipilih $\mathrm{pH}$ penetral 5 untuk pengujian IPLIT dikarenakan jumlah penetral yang dibutuhkan akan lebih sedikit dan memberikan keuntungan dari segi ekonomi.

Simulasi dilanjutkan pada Gambar 14 dengan input step berupa penambahan laju aliran penetral pada kondisi tertentu terhadap limbah dengan laju aliran konstan $0.8 \mathrm{~L} / \mathrm{m}$. Penetral asam pH 5 akan dinyalakan saat limbah berada di $\mathrm{pH} 9$ dan akan mati saat $\mathrm{pH} 8.2$ Hasil menunjukkan pada aliran maksimum $1 \mathrm{~L} / \mathrm{m}$ dibutuhkan waktu menyala hanya selama 190 detik sedangkan siklus 1 limbah mencapai 1542 detik. Berdasarkan kondisi ini, diharapkan dapat dilakukan penghematan terhadap penetral asam. 


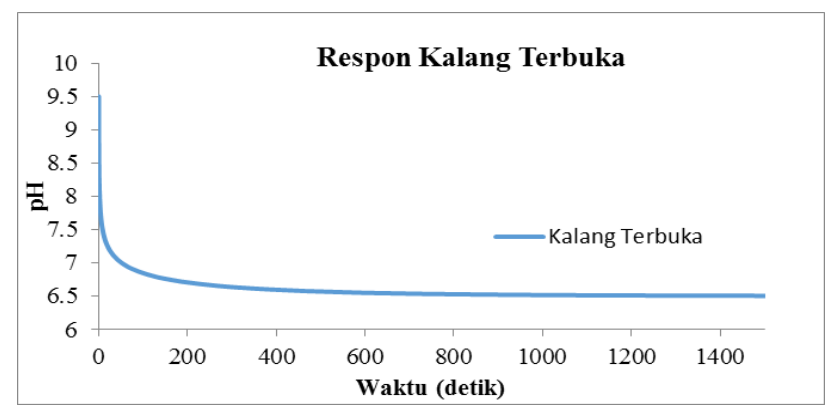

Gambar 10 Respon kalang terbuka pada $\mathrm{pH}$ limbah 9.5

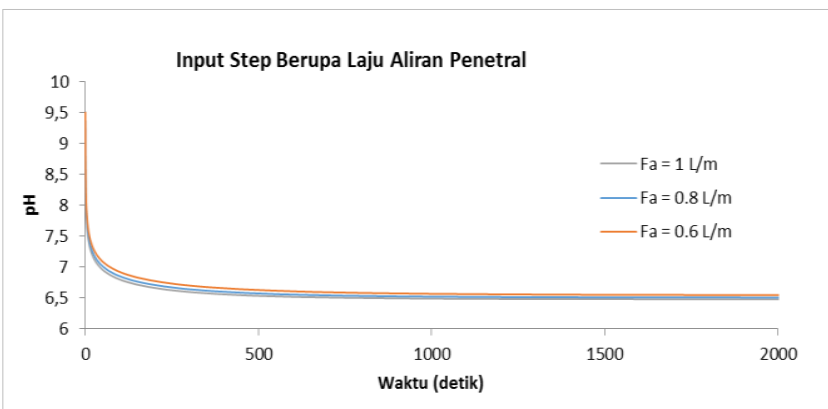

Gambar 11 Respon pH terhadap perubahan laju aliran penetral

\section{Kesimpulan}

1. Pada proses netralisasi plant simulator IPLIT dapat digunakan laju aliran masuk limbah 0.8 L/m dan $1 \mathrm{~L} / \mathrm{m}$, laju aliran masuk penetral asam antara $0.6 \mathrm{~L} / \mathrm{m}-1.0 \mathrm{~L} / \mathrm{m}$.

2. Konsentrasi limbah pada proses netralisasi $\mathrm{pH}$ adalah $\mathrm{pH}$ 9-10 dan konsentrasi penetral adalah $\mathrm{pH} 4-5$.

\section{Daftar Pustaka}

[1] Kemenperin: Industri Tekstil Tumbuh Baik. (26 September 2017). Data diperoleh melalui situs internet : http://industri.bisnis.com/ read/20170926/257/693248/kemenperinindustri-tekstil-tumbuh-baik. Diunduh pada tanggal 15 Februari 2018.

[2] Birry, A. A., dan Meutia, H., (2012) : Bahan Beracun Lepas Kendali " Sebuah Potret Pencemaran Bahan Kimia Berbahaya dan Beracun di Badan Sungai Serta Beberapa Titik Pembuangan Industri Tak Bertuan, Studi Kasus Sungai Citarum", Green Asia Tenggara Walhi Jawa Barat.

[3] Lebih dari 64 industri tekstil diduga buang limbah ke Citarum. ( 12 Januari 2018). CNN

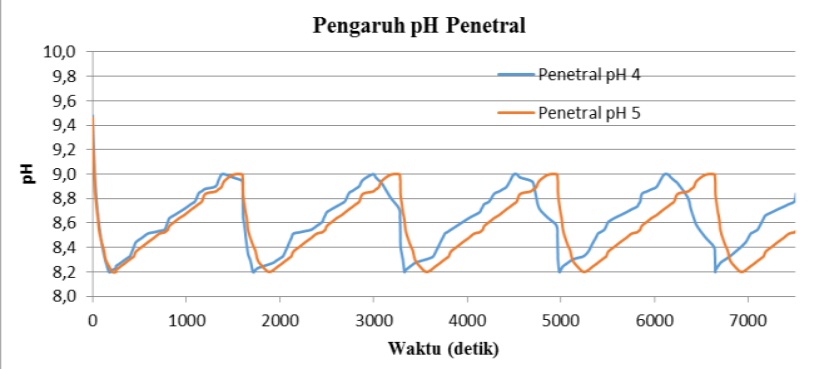

Gambar 123 Respon pH terhadap perubahan laju aliran penetral

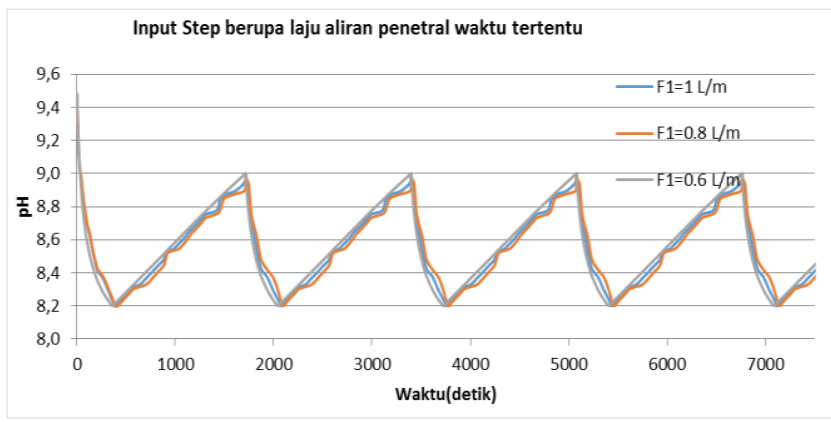

\section{Gambar 134 Respon pH 5 terhadap perubahan laju} aliran penetral

Indonesia, berita diperoleh melalui situs internet:https://www.cnnindonesia.com/ ekonomi/20180111214632-92-268281/ lebih-dari-64-industri-tekstil-diduga-buanglimbah-ke-citarum. Diunduh pada tanggal 18 Februari 2018.R.

[4] Keputusan Menteri Negara Lingkungan Hidup Nomor : KEP-51/MENLH/10/1995 tentang Baku Mutu Limbah Cair Bagi Kegiatan Industri, data diperoleh melalui situs internet: https://toolsfortransformation.net/wpcontent/uploads/2017/05/51-tahun-1995Baku-mutu-limbah-cair-industri.pdf. Diunduh pada tanggal 30 Januari 2018.

[5] Khandegar, V., Saroha, A.K., (2013) : Electrocoagulation for the treatment of tekstile industry effluent - a review, Journal of Environmental Management, 128, 949-963.

[6] Salehah, N.A., dan Hikmah, Q.M., (2016) : Pengolahan Air Limbah Industri Limbah Tekstil, Tugas Akhir Sarjana Teknik Fisika, Institut Teknologi Bandung.

[7] Alina, B., dan Madalina, C., (2016) : Internal model control for wastewater $\mathrm{pH}$ neutralization process, 8th International Conference Edition on Electronics, Computers, and Artificial Intelligence (ECAl).

[8] Youlin, Y., Qinghui, Wu.,(2016) : A neural network PID control for $\mathrm{pH}$ neutralization process, Proceeding of the 35th Chinese Control Conference, 3480-3483 